\title{
Use of TBM chips as concrete aggregate
}

\author{
Hp. Olbrecht, W. Studer \\ Swiss Federal Laboratories for Materials Testing and Research (EMPA), CH-8600 Dï̈cndorf, Suitzerland
}

\section{INTRODUCTION}

It has been known for some considerable time that available reserves of high-grade alluvial gravel in Switzerland will be practically exhausted in the foreseeable future [1] and that importing it from neighbouring states is hardly a permanent solution to the problem.

It can therefore be described as fortunate that in the near future a large number of tunnels are planned for construction and this will produce an enormous amount of tunnel excavation material.

For obvious reasons, there is more of this "waste product" than is needed for the tunnel construction itself. In addition, it is produced in a form that is very similar to gravel, especially when the excavation is carried out using tunnel boring machines (TBM).

Treated tunnel excavation material does not differ a great deal from crushed rock, stone chips and ballast. The technique for using this material to make concrete is well known and the fact that it is a full value substitute for alluvial gravel was recently shown dramatically on oil platforms in Norway. Of course, there are more problems associated with the production of concrete using TBM chips than with alluvial gravel. This production demands the application of state-of-the-art concrete technology and knowledge.

The processing of tunnel excavation material is very costly and results inevitably in a material loss which is not desirable for ecological reasons. For these reasons, laboratory investigations were carried out within the framework of the dissertation by Thalmann [2] with the aim of producing concrete using unprocessed tunnel excavation material. These investigations showed that this principle is possible and, under defined conditions, also economically interesting [3].

In order to determine whether these results are applicable in practice, five large scale trials were carried out which are briefly described in the following sections.

\section{LARGE-SCALE TRIALS}

\subsection{Organisation}

As determined by the general aims, the large-scale tests had to be carried out under building site conditions, which meant cooperation with concrete works and building contractors. The fifth test was carried out within the framework of a semester at the Institute of Technology State of Berne, Burgdorf.

During these tests, considerable good-will was required from all partners, as the material was rather unusual and because each had to bear the costs of the work carried out. We would therefore like to take this opportunity of thanking all those involved for their efforts, and we hope that it will pay off in the not too distant future.

\begin{tabular}{|c|c|c|c|c|}
\hline \multicolumn{5}{|c|}{ Table 1 - TBM material used } \\
\hline & Designation & Source & $\begin{array}{l}\text { Porosity } \\
\% \text { vol. }\end{array}$ & $\begin{array}{c}\text { Percentage of } \\
\text { non-cubical } \\
\text { grains }(8 / 16)\end{array}$ \\
\hline 1 & $\begin{array}{l}\text { Leventina Gneiss } \\
\text { biotite muscovite gneiss }\end{array}$ & $\begin{array}{l}\text { exploration tunnel Polmengo } \\
\text { tunnel metre: } 387 \ldots . . .390\end{array}$ & 36.6 & 74 \\
\hline II & Calcareous shale & Kandertal area & 42.1 & 76 \\
\hline III & $\begin{array}{l}\text { Biotite gneiss from } \\
\text { Lucomagno zone, shale- } \\
\text { like and slightly porphyritic }\end{array}$ & $\begin{array}{l}\text { exploration tunnel Polmengo } \\
\text { tunnel metre: } 4600\end{array}$ & 37.2 & 77 \\
\hline IV & Calcareous shale & $\begin{array}{l}\text { exploration tunnel Frutigen } \\
\text { section } 100 \ldots . . .1500 \mathrm{~m}\end{array}$ & 42.3 & 65 \\
\hline$v$ & Silicious limestone & $\begin{array}{l}\text { exploration tunnel Frutigen } \\
\text { tunnel metre: } 6500\end{array}$ & 41.8 & 89 \\
\hline 0 & Alluvial gravel & Swiss midland & 26.0 & 24 \\
\hline
\end{tabular}

\subsection{Determining the concrete composition}

During preparation work for NEAT (New Railway Alpine Transversal) and underground construction work in the Kandertal area of Switzerland, a large amount of TBM excavation material was produced. The aim of the internal EMPA tests was to determine whether this excavation material (see Table 1) could be used as concrete aggregate. The specific target was to produce an easily pumpable concrete with an average cube compressive strength of $35 \mathrm{~N} / \mathrm{mm}^{2}$ after 28 days (strength class 30/20). 


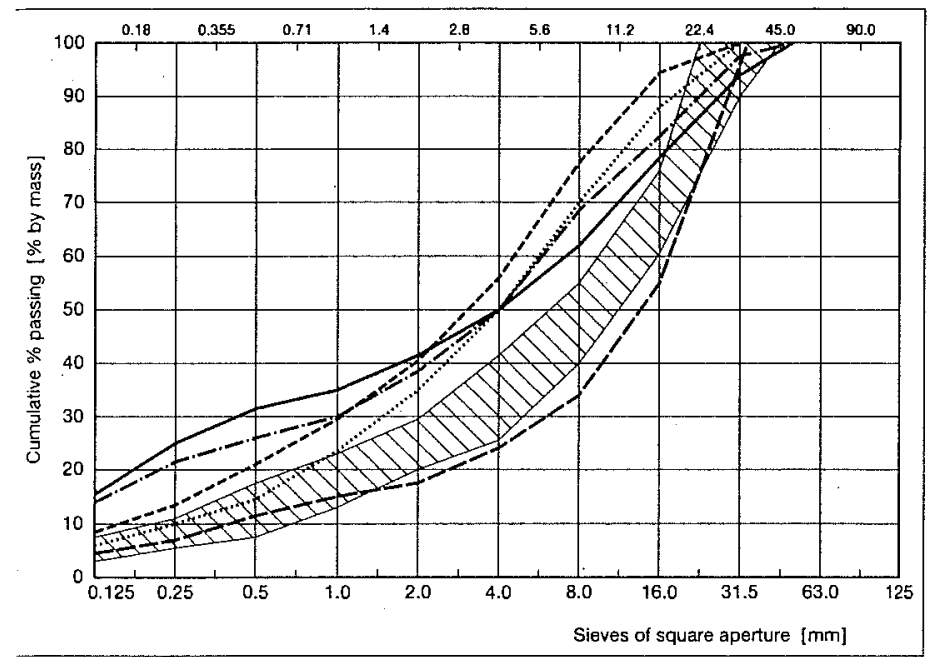

Fig. 1 - Particle size distribution of the 5 TBM materials (shaded area within SIA standard 162, art. 5, 14, 24; Fuller).

Apparently the particle size distribution, the porosity .d the percentage of unfavourably formed particles differed widely from that commonly associated with alluvial gravel. For this reason, laboratory tests had to be carried out in order to determine the concrete composition. These tests were based on two simple technical principles for concrete:

- Concrete is only easily processed if the volume of the cement paste (cement + water + air) is at least as large as the voids in a unit volume of aggregate.

- The compressive strength (fc $(28 \mathrm{~d})$ ) is dependent on the water-cement ratio $(\mathrm{w} / \mathrm{c})$ and the air void content $(\mathrm{a})$, according to the following formula:

$f_{c}(28 d)=100-110 \mathrm{w} / \mathrm{c}-(\mathrm{a}-1.5) \times 2\left[\mathrm{~N} / \mathrm{mm}^{2}\right]$

(valid for CEM I 32.5)

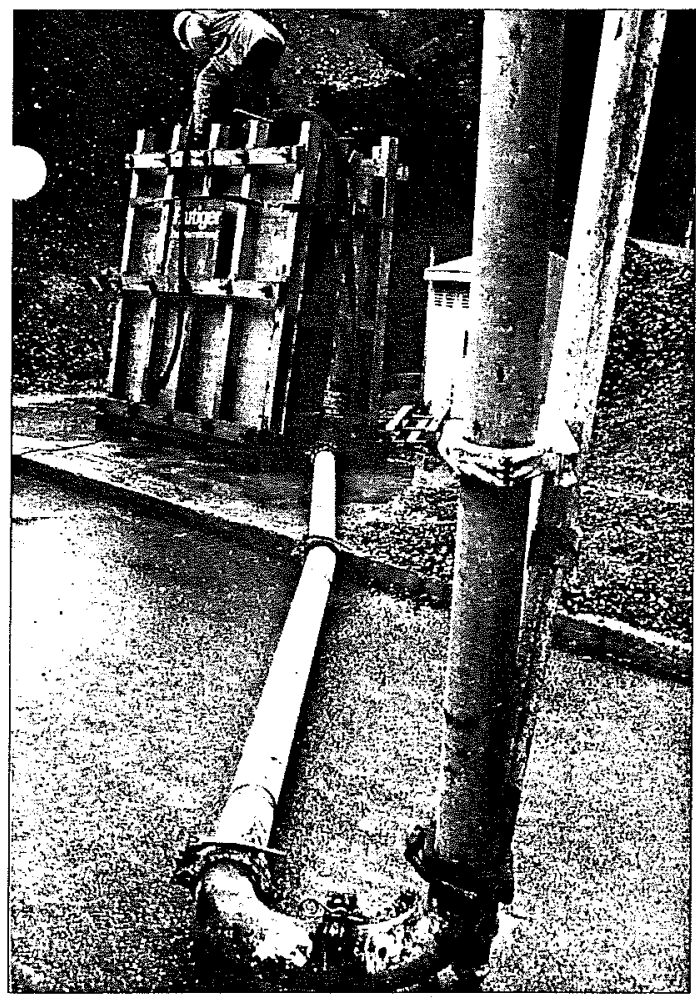

Fig. 2 - Transportation of concrete via pump.
This resulted in the concrete compositions quoted in Table 2 (see next page). It should be noted that a considerably higher amount of cement and admixtures was required than when alluvial gravel is used, although the targeted strength class was only 30/20. The air entraining agent was actually selected in order to achieve a high freeze-thaw resistance, but this proved to be advantageous, for less cement was needed.

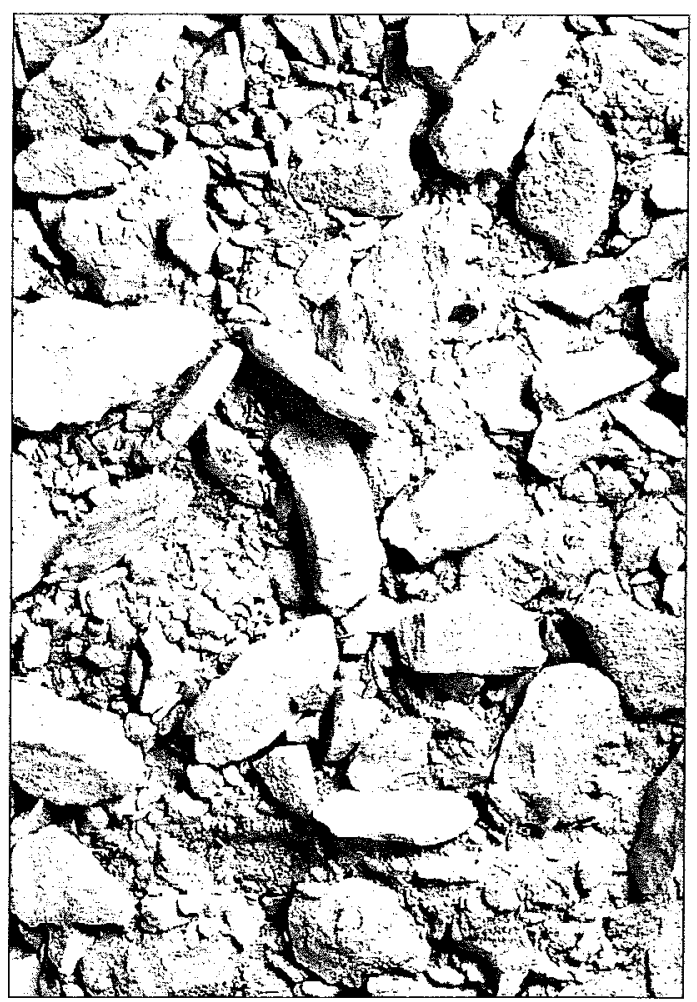

Fig. 3 - TBM material Polmengo.

\subsection{Test procedure}

The actual large-scale tests carried out in collaboration with a concrete works or a building contractor proceeded according to the following principles:

$-6 \ldots 8 \mathrm{~m}^{3}$ concrete was produced at a concrete factory and loaded onto a mixer truck.

- Before the truck left, approx. 100 litre of concrete was removed from the mixer in order to make a fresh concrete control (including the production of test specimens).

- The mixer truck transported the concrete (journey duration approximately 15 minutes).

- Another fresh concrete control was made.

- The concrete was pumped into the concrete mould (with the exception of the test with biotite gneiss).

- A third control was made on pumped fresh concrete.

-2 to 3 days after, the mould was removed and cores were taken from the hardened concrete.

The results of the fresh concrete checks and the investigations on hardened concrete are summarised in Tables 2 and 3. 


\subsection{Discussion of results}

All 54 tests produced well workable concrete suitable for building site use. However, the strength category $30 / 20$ was not quite reached on test number IV.

The emptying of the TBM chips from the silos required considerable manual work.
The modulus of elasticity was only approximately $40 . .57 \%$ of the value which could be expected when using aggregate from the Swiss midland.

The larger percentage of cement paste and the lower modulus of elasticity produced a considerably greater shrinkage deformation than with "conventional" concrete.

The effect of the air entraining agent and the stability of

\begin{tabular}{|c|c|c|c|c|c|}
\hline \multicolumn{6}{|c|}{ Table 2 - Concrete composition and fresh concrete properties } \\
\hline & & & Test & & \\
\hline Material & $\begin{array}{c}1 \\
\text { Exploration tunnel } \\
\text { Polmengo } \\
\text { (biotite mus- } \\
\text { covite gneiss) }\end{array}$ & $\begin{array}{c}\text { II } \\
\text { Area } \\
\text { Kandertal } \\
\text { (calcareous shale) }\end{array}$ & $\begin{array}{c}\text { III } \\
\text { Exploration tunnel } \\
\text { Polmengo } \\
\text { (biotite gneiss } \\
\text { from Lucomagno zone) }\end{array}$ & $\begin{array}{c}\text { IV } \\
\text { Exploration tunnel } \\
\text { Frutigen } \\
\text { (calcareous shale) }\end{array}$ & $\begin{array}{c}\mathrm{V} \\
\text { Exploration tunnel } \\
\text { Frutigen } \\
\text { (silicious limestone) }\end{array}$ \\
\hline $\begin{array}{l}\text { A Concrete mixture: } \\
\text { Aggregate } \\
\text { IBM material } \\
0 . .32 / 40 \quad \mathrm{~kg} / \mathrm{m}^{3} \\
\text { Cement } \quad \mathrm{kg} / \mathrm{m}^{3} \\
\text { Water } \\
\text { w/c ratio } \\
\text { Water reducing agent } \\
\text { in mass \% of Cement } \\
\text { Air entraining agent } \\
\text { in mass \% of Cement }\end{array}$ & $\begin{array}{c}1680 \\
380 \\
239 \\
0.63 \\
1.5 \\
0.2\end{array}$ & $\begin{array}{c}1660 \\
380 \\
230 \\
0.61 \\
1.2 \\
0.4\end{array}$ & $\begin{array}{c}1630 \\
385 \\
235 \\
0.61 \\
\\
1.5 \\
0.25\end{array}$ & $\begin{array}{c}1610 \\
390 \\
250 \\
0.64 \\
1.4 \\
0.3 \\
\end{array}$ & $\begin{array}{c}1680 \\
380 \\
228 \\
0.60 \\
1.2 \\
0.2 \\
\end{array}$ \\
\hline 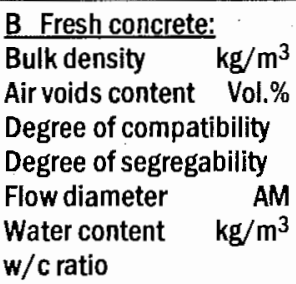 & $\begin{array}{c}2219 \\
4.8 \\
1.26 \\
1.16 \\
360 \\
240 \\
0.63\end{array}$ & $\begin{array}{c}2252 \\
3.3 \\
1.13 \\
1.04 \\
390 \\
249 \\
0.66\end{array}$ & $\begin{array}{c}2312 \\
2.4 \\
1.14 \\
2.27 \\
340 \\
235 \\
0.61\end{array}$ & $\begin{array}{c}2239 \\
3.8 \\
1.25 \\
1.04 \\
370 \\
260 \\
0.67\end{array}$ & $\begin{array}{c}2271 \\
4.4 \\
1.08 \\
\\
360 \\
245 \\
0.65\end{array}$ \\
\hline
\end{tabular}

Remark: For tests I, II and IV the concrete was taken before the pump and for $V$ after the pump, for test III (not pumped) during the placing of the concrete.

\begin{tabular}{|c|c|c|c|c|c|}
\hline \multicolumn{6}{|c|}{ Table 3 - Hardened concrete on determined cores } \\
\hline & & & Test & & \\
\hline Test value & $\begin{array}{c}\text { I } \\
\text { Exploration tunnel } \\
\text { Polmengo } \\
\text { (biotite muscovite- } \\
\text { gneiss) }\end{array}$ & $\begin{array}{c}\| \\
\text { Area } \\
\text { Kandertal. } \\
\text { (calcareous shale) }\end{array}$ & $\begin{array}{c}\text { III } \\
\text { Exploration tunnel } \\
\text { Polmengo } \\
\text { (biotite gneiss } \\
\text { from Lucomagno zone) }\end{array}$ & $\begin{array}{l}\text { IV } \\
\text { Exploration tunnel } \\
\text { Frutigen } \\
\text { (calcareous shale) }\end{array}$ & $\begin{array}{c}v^{\mathbf{3})} \\
\text { Exploration tunnel } \\
\text { Frutigen } \\
\text { (silicious limestone) }\end{array}$ \\
\hline $\begin{array}{l}\text { Compressive strength } \mathrm{fc} \\
\text { Age } 28 \text { days }\left[\mathrm{N} / \mathrm{mm}^{2}\right] \\
\text { Modulus of elasticity }\end{array}$ & 30.5 & 34.4 & 37.1 & 23.9 & 32.4 \\
\hline Age 28 days $\left[\mathrm{N} / \mathrm{mm}^{2}\right]$ & $13 ' 500$ & $19^{\prime} 700$ & $17 ' 800$ & $11^{\prime} 800$ & $27 ' 300$ \\
\hline $\begin{array}{l}E / \sqrt{f_{c}} \\
\text { Water conductivity }\end{array}$ & 2444 & 3359 & 2922 & 2414 & 4716 \\
\hline $\begin{array}{l}\text { qw }\left[\mathrm{g} / \mathrm{m}^{2} \mathrm{~h}\right] \\
\text { Shrinkage value } \\
\text { 1) }\end{array}$ & 19 & 23 & 17 & 25 & 10 \\
\hline $\begin{array}{lr}\text { after } 28 \text { days } & {[\% 0]} \\
\text { Air voids content } & \text { a }\end{array}$ & 0.47 & 0.52 & 0.24 & 0.90 & 0.36 \\
\hline $\begin{array}{l}\text { - Outer layer [Vol.\%] } \\
\text { Freeze-thaw resistance }\end{array}$ & 5.71 & 1.80 & 2.41 & 4.28 & 1.47 \\
\hline $\begin{array}{l}\text { - Outer layer } \\
\text { a } / n-U_{k r}=F S \\
\text { Assessment } \\
\text { Deicing salt resistance }\end{array}$ & $\begin{array}{c}1.5 \ldots 1.7 \\
\text { high }\end{array}$ & $\begin{array}{c}0.5 \ldots 1.1 \\
\text { low....medium }\end{array}$ & $\begin{array}{l}1.1 \ldots 1.2 \\
\text { medium }\end{array}$ & $\begin{array}{l}1.2 \ldots 1.5 \\
\text { medium..high }\end{array}$ & $\begin{array}{c}1.2 \\
\text { medium } \\
1.47\end{array}$ \\
\hline $\begin{array}{ll}\Delta \mathrm{m}_{30} & {\left[\mathrm{~g} / \mathrm{m}^{2}\right]} \\
\text { Assessment } & \end{array}$ & $\begin{array}{l}700 \ldots . . .4400 \\
\text { medium...low }\end{array}$ & $\begin{array}{l}14^{\prime} 500 \\
\text { low }\end{array}$ & $\begin{array}{l}8^{\prime} 400 \\
\text { low }\end{array}$ & $\begin{array}{c}9100^{2)} \\
\text { low }\end{array}$ & $\begin{array}{c}1400 \\
\text { medium }\end{array}$ \\
\hline
\end{tabular}

1) At $20^{\circ} \mathrm{C} / 70 \%$ r.h. 2) After 20 freeze-thaw cycles. 3) Determined on specimens made from the laboratory mix during the preliminury investigations. 
the air void system apparently depend to a great extent on the type of aggregate used. In addition, the freeze-thaw resistance of the outer layer was greatly overestimated on the basis of the porosity values.

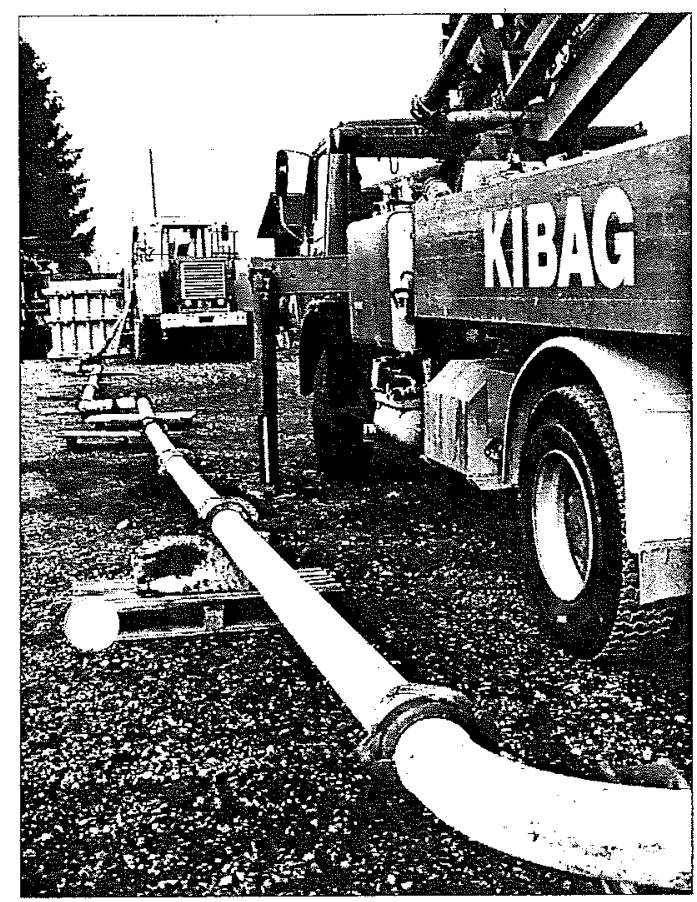

Fig. 4 - Pump with pipeline for the concrete.

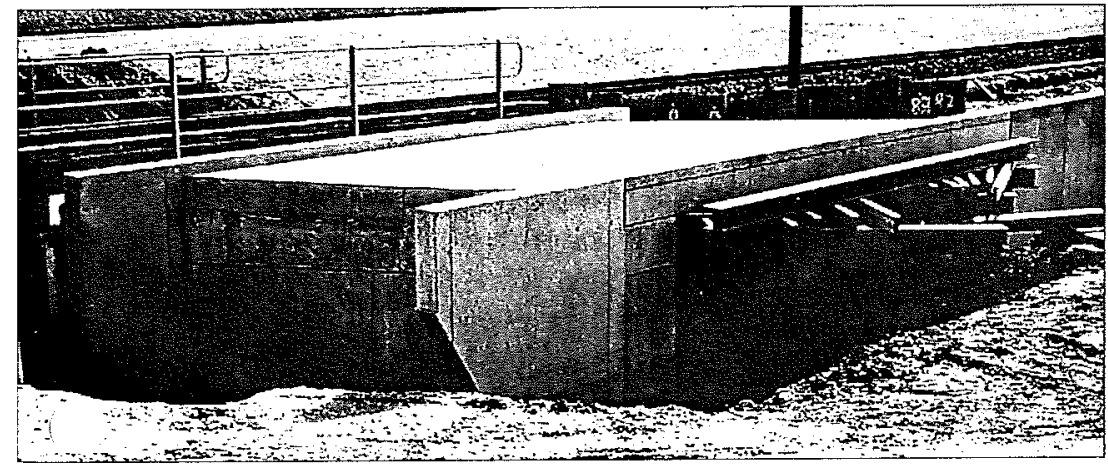

Fig. 5 - Completed 'wing wall' at location.

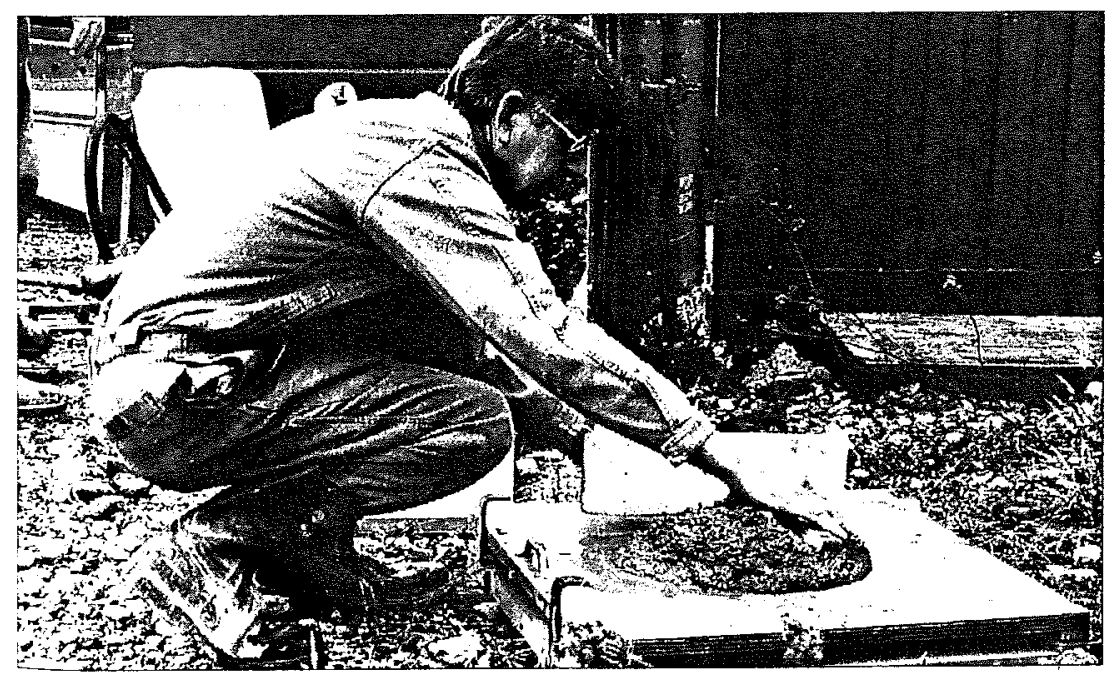

Fig. 6 - Determining flow diameters.

\section{FUTURE PROSPECTS}

Even using untreated TBM chips, it is possible to produce concrete suitable for building site use. But with calcareous shale, the limit of application as concrete aggregate seemns to be reached.

Nevertheless, the processes still need some inprovement before being introduced, so that even untreated TBM chips can be used on a large scale as a substitute for gravel. For instance, it can be assumed that silos are a fairly unsuitable method to store this material which shows widely scattering characteristics as well as a tendency to clog. With modifications in storage, the conveyance method to the mixer would also change, and in addition there are other and more measurements on the aggregate necessary for the production control than are currently carried out.

Therefore, new ideas are requested and investment required in the production of concrete - an effort which seems hardly worthwhile by looking at the result: out of all these efforts we get anything else but a "high performance concrete".

However, considering the fact that the majority of concrete is used in standard building construction and that high grade aggregate is getting scarce and expensive, it is clear that this new source of aggregate, currently graded low, could become a decisive factor for the future of concrete construction. It will be increasingly necessary to make the most of the materials in order to save high grade material for high grade projects.

In a sense, the concrete produced in these large-scale tests is still a kind of "high performance concrete", the maximum which could have been achieved by using raw TBM chips when considering the prevailing conditions. We are convinced that such concrete with "matched efficiency", resulting from the necessarily growing use of alternative materials, will be the greatest challenge for concrete manufacturers, specialists and testers.

\section{REFERENCES}

(1) Jäckli, H. and Schindler, C., 'Möglichkeiten der Substitution hochwertiger Alluvialkiese durch andere mineralische Rohstoffe', Beiträge zur Geologie der Schweiz Geotechnische Serie Lieferung 68, Bern, 1986.

[2] Thalmann, C., 'Beurteilung und Möglichkeiten der Wiederverwertung von Ausbruchmaterial aus dem maschinellen Tunnelvortrieb zu Betonzuschlagstoffen', Diss. ETH Nr. 11721, ETH Zürich, 1996.

[3] Olbrecht, H.P. and Studer, W., 'Beton aus TBM-Chips', Schweizer Baublatt Nr. 81, 10, Oktober 1995 